\title{
G. Agresti (cur.), Antologia de la nòva escritura occitana - Anthologie de la nouvelle écriture occitane.
} 1980-2000

\section{Chiara Preite}

\section{(2) OpenEdition Journals}

Édition électronique

URL : http://journals.openedition.org/studifrancesi/35192

DOI : 10.4000/studifrancesi.35192

ISSN : 2421-5856

Éditeur

Rosenberg \& Sellier

Édition imprimée

Date de publication : 1 novembre 2005

Pagination : 451

ISSN : 0039-2944

\section{Référence électronique}

Chiara Preite, « G. Agresti (cur.), Antologia de la nòva escritura occitana - Anthologie de la nouvelle écriture occitane. 1980-2000 », Studi Francesi [En ligne], 146 (XLIX | II) | 2005, mis en ligne le 30 novembre 2015, consulté le 19 avril 2021. URL : http://journals.openedition.org/studifrancesi/35192 ; DOI : https://doi.org/10.4000/studifrancesi.35192

Ce document a été généré automatiquement le 19 avril 2021.

\section{cc) $($ ) $\ominus$}

Studi Francesi è distribuita con Licenza Creative Commons Attribuzione - Non commerciale - Non opere derivate 4.0 Internazionale. 


\title{
G. Agresti (cur.), Antologia de la nòva escritura occitana - Anthologie de la nouvelle écriture occitane. 1980-2000
}

\author{
Chiara Preite
}

\section{RÉFÉRENCE}

G. AGRESTI (cur.), Antologia de la nòva escritura occitana - Anthologie de la nouvelle écriture occitane. 1980-2000, Jorn et Le Temps des Cerises, Saint-Germain-du-Puy, 2004, pp. 242.

1 Cette anthologie, présentée par G. AGRESTI et financée entièrement par la Région Languedoc-Roussillon, fait le point sur la création littéraire occitane de ces vingt dernières années. À un recueil de 28 textes, entre contes et poèmes, accompagnés par leur traduction en français (parfois fournie par les auteurs mêmes), fait suite une section comprenant une série de notices biographiques sur les auteurs des œuvres retenues: Jean-Yves Casanova, Jean-Paul Creissac, Jean-Claude Forêt, Jean Ganhaire, Philippe Gardy, Francis Gazanhes, Éric Gonzalès, Jean-François Mariot, Jan Dau Melhau, Michel Miniussi, Roland Pécout, Alain Peillon, Jean-Marie Pieyre, Jacques Privat, Roselyne Roche, Jean-Yves Royer, Claudio Salvagno, Jean-Luc Sauvaigo, Alain SurreGarcia, Jean-Pierre Tardif, Florian Vernet et Adeline Yzac sont les divulgateurs modernes de la langue des troubadours. La préface de Robert LAFONT, manifeste de cet art «nouveau» aux racines lointaines, décrit ces auteurs - peu connus par les Occitanes eux-mêmes - comme des écrivains capables de réveiller la littérature occitane à travers le renouveau de la langue qui l'exprime, sans renoncer à la modernité des temps qu'ils expérimentent. Ces auteurs manifestent leur cosmopolitisme moderne et, s'appuyant sur une tradition séculaire, posent un «socle à la nouveauté». 